\title{
In vitro culture of Perkinsus atlanticus, a parasite of the carpet shell clam Ruditapes decussatus
}

\author{
M. C. Ordás, A. Figueras * \\ Instituto de Investigaciones Marinas, Consejo Superior de Investigaciones Científicas (CSIC), Eduardo Cabello, 6 , \\ E-36208 Vigo, Spain
}

\begin{abstract}
The ability to mass-culture parasites in vitro facilitates biological, metabolic and morphological research that would otherwise be difficult to accomplish. In vitro continuous culture of the protistan Perkinsus atlanticus from carpet-shell clam was established and variables including culture medium, inoculum size, temperature and salinity, which affect parasite proliferation, were studied. This parasite can adapt to very different culture media and salinity and temperature conditions, and the inoculum density does not affect the final cellular concentration attained in vitro. The morphology of cultured $P$. atlanticus is described and its optimum in vitro growth conditions were compared with those for $P$. marinus, a parasite of the eastern oyster Crassostrea virginica. Cryopreservation of cultured $P$. atlanticus was developed to assure the long-term storage of this parasite.
\end{abstract}

KEY WORDS: Perkınsus atlanticus Clams - Protıstan Protozod Parasite In vitro - Ruditapes decussatus

\section{INTRODUCTION}

Since it was first described, Perkinsus marinus has been associated with oyster Crassostrea virginica mortalities (Burreson et al. 1994, Andrews 1996). It was believed to be a fungus and was given the name Dermocystidium marinum (Mackin et al. 1950). The simple diagnostic method developed by Ray $(1954,1996)$. using fluid thioglycollate medium, with its later modifications (Fisher \& Oliver 1996), facilitated research on different aspects of the parasite's life cycle and its relationship with the host. Based on observations of amoeboid stages of the parasite in oysters, the name was changed to Labyrinthomyxa marina (Mackin \& Ray 1966). Finally, because of the apical complex observed by electron microscopy in the infective motile zoospores (Perkins \& Menzel 1967), the protist was included in the phylum Apicomplexa. The new class Perkinsea, the order Perkinsida and the family Perkinsidae were established to include the species $P$. marinus (Levine 1978). Later, other species of the genus

·Addressee for correspondence. E-mail: pato1@iim.csic.es were described: P. olseni (parasite of the abalone Haliotis ruber) (Lester \& Davis 1981) and P. karlssoni (parasite of the bay scallop Argopecten irradians) (McGladdery et al. 1991, Whyte et al. 1993), although the latter name was subsequently withdrawn (Goggin et al. 1996). Several other Perkinsus spp. have been identified in various molluscs, including Tridacna maxima and Saccostrea cucculata (Perkins 1985), the goldenlipped pearl oyster Pinctada maxima (Norton et al. 1993), Macoma balthica (Kleinschuster et al. 1994). and in several populations of 30 different bivalve species of the Australian Great Barrier Reef (Goggin \& Lester 1987).

Azevedo (1989) and Azevedo et al. (1990) described the fine structure of a parasite identified as Perkinsus sp. causing mortalities of the carpet shell clam Ruditapes decussatus on the coast of southern Portugal. Based on ultrastructural characteristics, a new species, P. atlanticus, was established (Azevedo 1989). Various environmental conditions, including temperature, salinity, $\mathrm{pH}$ and dissolved oxygen, were tested for the in vitro sporulation of this parasite, resulting in values very similar to those reported for $P$. marinus (AuzouxBordenave et a]. 1995). 
In 1987, the presence of a Perkinsus-like organism was associated with heavy mortalities of the clam Ruditapes decussatus (Figueras et al. 1992). Subsequently, many similar infections occurred along the Galician coast (NW Spain) in both carpet shell clams $R$. decussatus and manila clams $R$. philippinarum (Figueras et al. 1996).

Several authors have developed in vitro cultures of Perkinsus marinus and Perkinsus sp. found in several hosts in order to obtain an axenic source of the parasite with which to study different aspects of its life cycle (Gauthier \& Vasta 1993, 1995, Kleinschuster \& Swink 1993, La Peyre et al. 1993, Kleinschuster et al. 1994, Gauthier et al. 1995, La Peyre 1996). In this paper, the in vitro culture conditions for $P$, atlanticus are established. This methodology will facilitate comparison of the European and North American species.

\section{MATERIALS AND METHODS}

Clams. Infected clams Ruditapes decussatus were collected from the Ría de Pontevedra (Galicia, NW Spain) in August 1996. Clams were maintained at $15^{\circ} \mathrm{C}$ and $35 \%$ salinity in aerated tanks and were fed daily with the algae Isochrysis galbana and Tetraselmis svecica.

Diagnosis and detection. The presence of Perkinsus atlanticus in clams was assessed using Ray's Fluid Thioglycollate Medium (RFTM). Briefly, gills of gaping clams were introduced into RFTM (Ray 1954). Nystatin was added prior to introducing tissue, to reduce fungal contamination. After $3 \mathrm{~d}$ of incubation in the dark at room temperature $\left(21^{\circ} \mathrm{C}\right)$, gills were placed on a slide, stained with Lugol's iodine and observed with a light microscope. This method was used to select the most parasitized clam population from which the $P$. atlanticus primary cultures were obtained.

Establishment of Perkinsus atlanticus primary cultures. One $\mathrm{ml}$ of blood from the adductor muscle was extracted from each individual with an insulin syringe and seeded in 24-well polystyrene plates. One ml of $35 \%$ sterile artificial sea water (ASW) prepared with Marine Mix (Sigma) with 4000 I.U. $\mathrm{ml}^{-1}$ penicillin/ streptomycin (P/S) (to prevent bacterial growth) was added to each well, and, after $12 \mathrm{~h}$ of incubation at $26^{\circ} \mathrm{C}$, contents of the wells were pooled and centrifuged for $10 \mathrm{~min}$ at $1500 \times \mathrm{g}$. The pellet was resuspended in ASW with 4000 I.U. $\mathrm{ml}^{-1} \mathrm{P} / \mathrm{S}$ and incubated for another $12 \mathrm{~h}$ at $26^{\circ} \mathrm{C}$. Cells were centrifuged again and the supernatant was carefully removed from each well. Then, $1 \mathrm{ml}$ of Dulbecco's Modified Eagle Medium (DMEM):Ham's F-12 (1:2) with $50 \mathrm{mM}$ Hepes buffer, $3.5 \mathrm{mM}$ sodium bicarbonate and $5 \%$ Foetal Bovine
Serum (FBS) in 35\% ASW (Gauthier \& Vasta 1995) was added to each well. During the first week the medium was changed twice, and when the number of Perkinsus cells was over $10^{7}$ cells $\mathrm{ml}^{-1}$, another subculture was initiated.

Electron microscopy of zoospores. Perkinsus cultures in the exponential phase of growth were transferred from culture medium to $35 \%$ ASW, and, when zoosporulation occurred, the cell suspension was pelleted at $100 \times g$ for $10 \mathrm{~min}$ to separate zoospores from the remaining Perkinsus developmental stages. The supernatant, containing zoospores, was fixed for $2 \mathrm{~h}$ using $1 \% \mathrm{OsO}_{4}$ prepared in $2 \%$ cacodylate buffer. Drops of this zoospore suspension were placed on formvar-coated grids. After $30 \mathrm{~min}$, the excess liquid was removed with filter paper. This procedure was carried out with several cultured $P$. atlanticus stocks. Grids were observed with a transmission electron microscope (Phillips CM 100).

Assessment of growth rate. Growth rate was determined daily by direct counting using a hemocytometer. Briefly, $10 \mu \mathrm{l}$ of cell suspension was placed in a Neubauer chamber and counted under the microscope. When the cell number was high (up to $10^{6}$ cells $\mathrm{ml}^{-1}$ ) a 1:10 dilution was made and counted as above. Mean and standard deviation were calculated from 4 counts.

Selection of Perkinsus atlanticus in vitro culture medium. Three different culture media [ASW; Minimum Essential Medium (MEM with $0.25 \%$ sodium bicarbonate); and DMEM:Ham's F-12 (1:2) with $50 \mathrm{mM}$ Hepes buffer and $3.5 \mathrm{mM}$ sodium bicarbonate], with 2 FBS concentrations for each medium (5 and 10\%), were tested at $26^{\circ} \mathrm{C}$. All media were prepared in $35 \%$ ASW with 100 I.U. $\mathrm{ml}^{-1}$ of $\mathrm{P} / \mathrm{S}$

Optimization of culture conditions. The effect of inoculum density, temperature and salinity on the proliferation of Perkinsus atlanticus was determined (4 replicates in each sampling) using in all cases DMEM:Ham's F-12 (1:2) with 50 mM Hepes buffer and $3.5 \mathrm{mM}$ sodium bicarbonate plus FBS as culture medium

Three initial densities $\left(10^{4}, 10^{5}\right.$ and $10^{6}$ cell $\left.\mathrm{ml}^{-1}\right)$ of Perkinsus atlanticus were used as inocula to begin the culture at $26^{\circ} \mathrm{C}$. The $10^{6}$ cell $\mathrm{ml}^{-1}$ inoculum was not retained because it was too concentrated, considering the final density reached by the cultures (slightly over $10^{7}$ cells $\mathrm{ml}^{-1}$ ).

The effect of temperature on growth rate was determined by incubating separate plates with the same inoculum density $\left(10^{4}\right.$ cells $\left.\mathrm{ml}^{-1}\right)$ at $5,16,20,26$ and $37^{\circ} \mathrm{C}$. The growth rate at $26^{\circ} \mathrm{C}$ was also measured using media prepared at 4 salinities $(15,25,35$ and 40$)$, which were obtained by changing the amount of salts used when preparing the medium. 
Cryopreservation. Cryopreservation of Perkinsus atlanticus was performed following Gauthier \& Vasta (1995). Briefly, cells in the exponential phase of growth were pelleted and resuspended in $40 \%$ DMEM Ham's F-12 (1:1) with 10\% DMSO (dimethyl sulfoxide) and $50 \%$ FBS. The cell suspension was aliquoted into cryovials and cooled gradually $\left(15\right.$ min at $5^{\circ} \mathrm{C}, 2 \mathrm{~h}$ or overnight at $-20^{\circ} \mathrm{C}$ and finally kept at $-70^{\circ} \mathrm{C}$ ). To test the viability of the frozen culture, the cryovials were thawed after 5 mo in a $70 \%$ ethanol bath, and the contents washed twice, resuspended in DMEM:Ham's F-12 (1:2) with $50 \mathrm{mM}$ Hepes buffer and $3.5 \mathrm{mM}$ sodium bicarbonate with $5 \%$ FCS and incubated under the standard conditions mentioned above.

\section{RESULTS}

\section{Ray's fluid thioglycollate test}

Some gills contained large, spherical blue-black cells, mostly in multicellular groups. This allowed presumptive identification of Perkinsus sp and the selection of the most infected population for initiation of primary cultures.

\section{Morphology of cultured Perkinsus atlanticus}

In all contrasted preparations derived from different culture stocks, zoospores had a unilateral array of filamentous mastigonemes along the anterior flagellum (Fig. 1), indicating that they were not a species of thraustochylrid. Moreover, laminated cell walls, characteristic of thraustochytrids, were never observed using transmission electron microscopy; ectoplasmic networks were never observed in these cultures.

The first observed stages in the Perkinsus atlanticus cultures were hypnospores, which appeared in the hemolymph that had been seeded in ASW plus antibiotics. These were large spherical bodies with an eccentric vacuole that occupied almost all the cell. Several refringent lipid droplets were observed.

Twenty four hours after the DMEM:Ham's F-12 (1:2) with $50 \mathrm{mM}$ Hepes buffer and $3.5 \mathrm{mM}$ sodium bicarbonate with $5 \%$ FBS had been added to the hypnospores, they turned granular and opaque, and small immature trophozoites were released by rupture of the cell wall. These immature trophozoites grew and became refringent. In some cultures the size of mature trophozoites did not increase and they acquired a uni- form polygonal morphology without increasing the number of $P$. atlanticus cells. In other cultures trophozoites became spherical, with a peripheral ring formed by the cytoplasm being pressed against the cell wall by the enlarged eccentric vacuole (Fig. 2A). Before the first binary fission the cytoplasm became foamy and 2, 4 or more cell stages were seen (Fig. 2B). After successive divisions the mother cell became very dark, due to the abundance of daughter cells. These immature trophozoites were released by rupture of the mother cell wall (Fig. 2C). In a few cases development of the discharge tube could be seen. If the culture was maintained in optimum conditions this cycle was continuously repeated. If the culture medium was not renewed, trophozoites became small and irregular in shape, forming cloudy clumps that grew in all directions. This stage had a very low growth rate without enlargement of daughter cells and maintained the same appearance for extended periods of time.

The presence of motile zoospores, deriving probably from mother cells with a discharge tube, was observed 4 or $5 \mathrm{~d}$ after initiation of primary cultures. This stage was most often seen when the initial hypnospores were released in ASW; zoosporulation was a massive event.

Another atypical event was a connection formed between 2 individual cells with 'cytoplasmic bridges' (Fig. 3A). Bipartitions of individual mature trophozoites were also observed, producing 2 daughter cells (Fig. 3B). It was difficult to ascertain whether there was any kind of nuclear mixing. Ectoplasmic nets were never observed in cultured cells.

\section{Selection of Perkinsus atlanticus in vitro culture medium}

The proliferation of Perkinsus atlanticus in different media is represented in Fig. 4. The division rates 

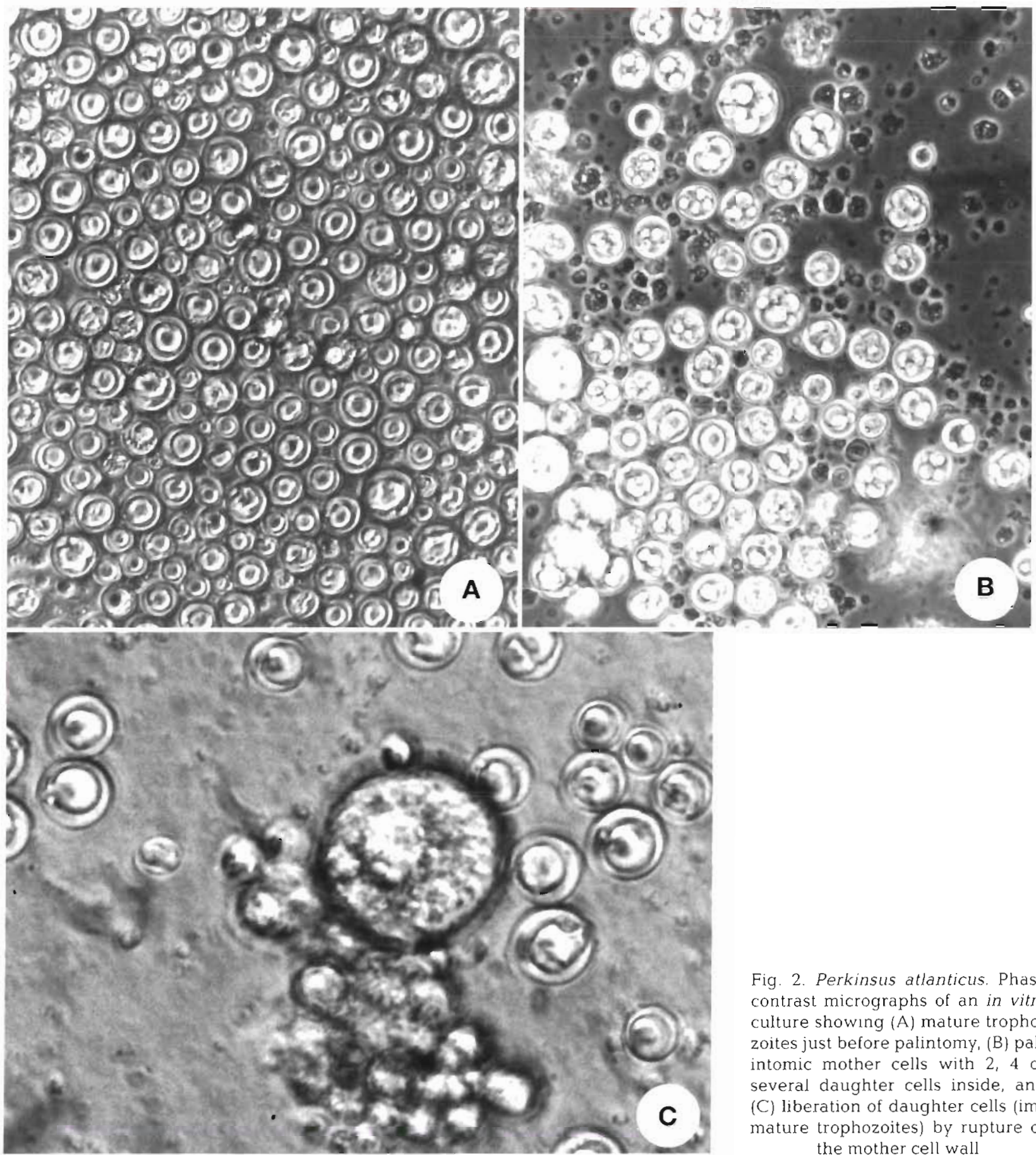

Fig. 2. Perkinsus atlanticus. Phase contrast micrographs of an in vitro culture showing (A) mature trophozoites just before palintomy, (B) palintomic mother cells with 2, 4 or several daughter cells inside, and (C) liberation of daughter cells (immature trophozoites) by rupture of the mother cell wall

obtained both in DMEM:Ham's F-12 (1:2) with 50 mM Hepes buffer and $3.5 \mathrm{mM}$ sodium bicarbonate and in MEM were similar, although slightly higher in the former. The final cellular densities obtained in the 2 media were $1.5 \times 10^{7}$ cells $\mathrm{ml}^{-1}$ in DMEM:Ham's F-12 (1:2) with $50 \mathrm{mM}$ Hepes buffer and $3.5 \mathrm{mM}$ sodium bicarbonate plus $5 \% \quad F C S ; 3 \times 10^{7}$ cells $\mathrm{ml}^{-1}$ in DMEM:Ham's F-12 (1:2) with 50 m.M Hepes buffer and
$3.5 \mathrm{mM}$ sodium bicarbonate plus $10 \%$ FBS; $6.3 \times 10^{6}$ cells $\mathrm{ml}^{-1}$ in MEM with $0.25 \%$ sodium bicarbonate plus

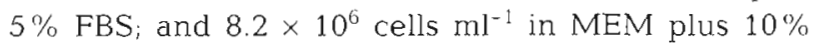
FBS. No changes were observed in parasite morphology when different media were used.

Massive zoosporulation occurred in ASW plus $5 \%$ FBS at Day 7 and at Day 9 in ASW plus $10 \%$ FBS. Subsequently, no more counts were conducted. 

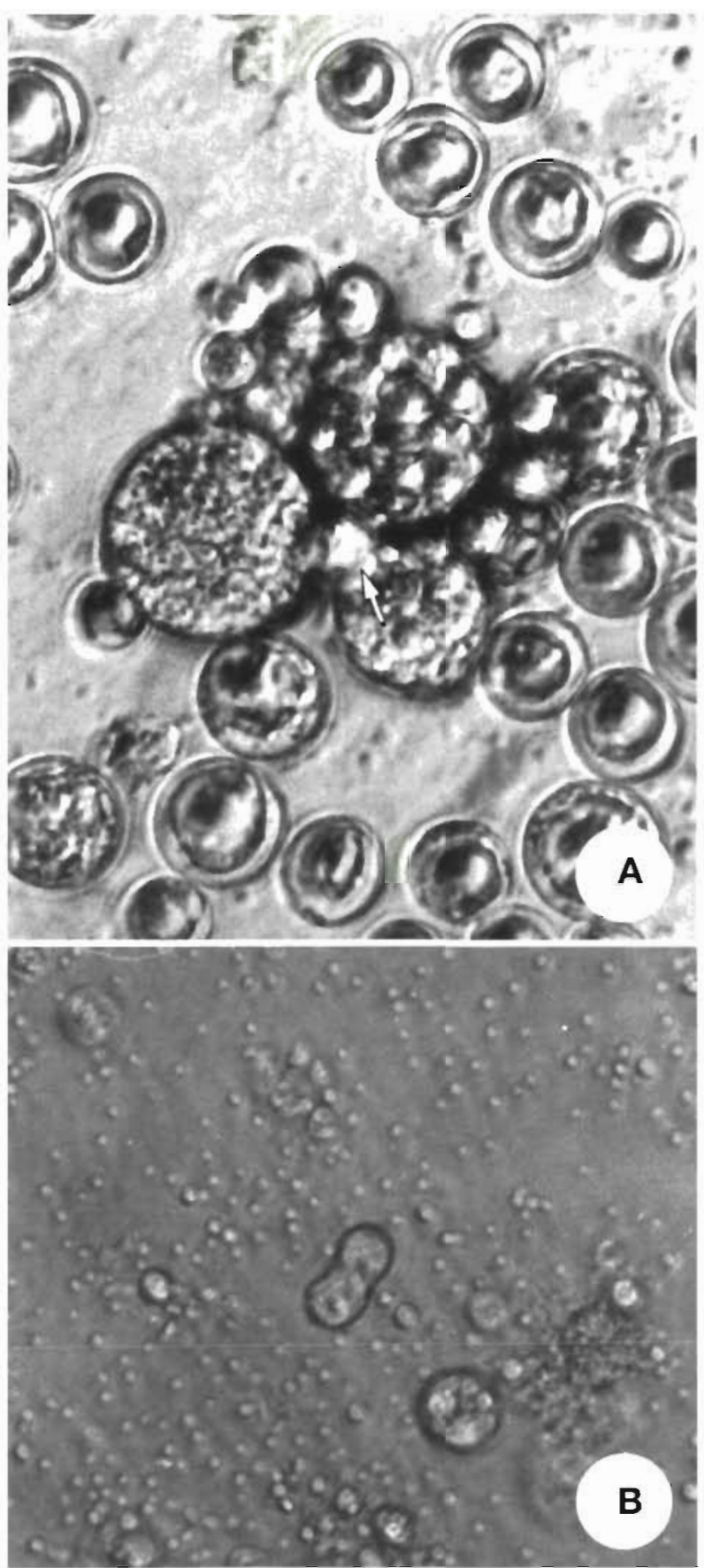

Fig. 3. Perkinsus atlanticus. Phase contrast micrographs of rarely observed stages of an in vitro culture showing (A) 'cytoplasmic bridges' (arrow) between individual cells and (B) bipartition of an immature trophozoite in a high density culture

\section{Optimization of culture conditions}

The inoculum size $\left(10^{4}\right.$ and $10^{5}$ cells $\left.\mathrm{ml}^{-1}\right)$ did not influence the final density of Perkinsus atlanticus cells after $10 \mathrm{~d}$ of culture (Fig, 5).
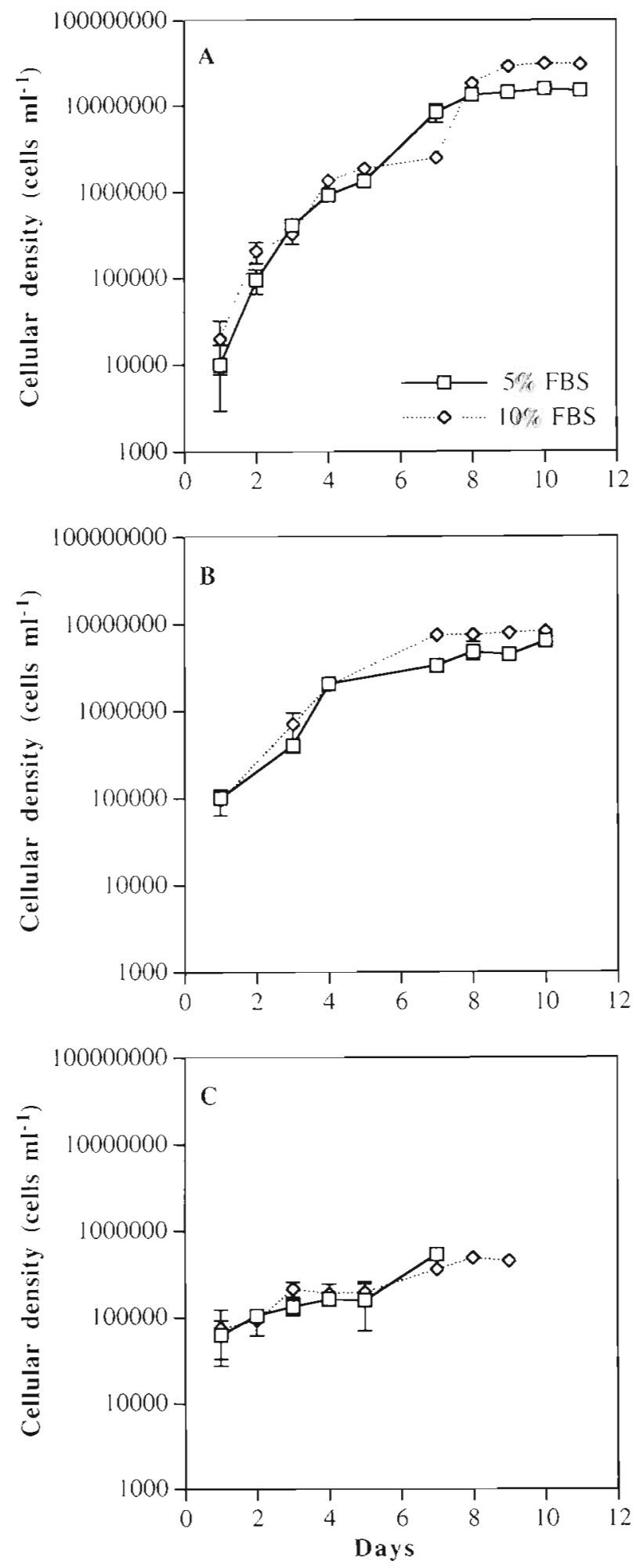

Fig. 4. Perkinsus atlanticus. Growth in (A) DMEM:Ham's F-12 (1:2) with $50 \mathrm{mM}$ Hepes buffer and $3.5 \mathrm{mM}$ sodium bicarbonate, (B) Minimum Essential Medium (MEM) and (C) artificial sea water (ASW), at 2 different concentrations ( 5 and $10 \%$ ) of Foetal Bovine Serum (FBS). Results are shown as mean with standard deviation $(n=4)$ 


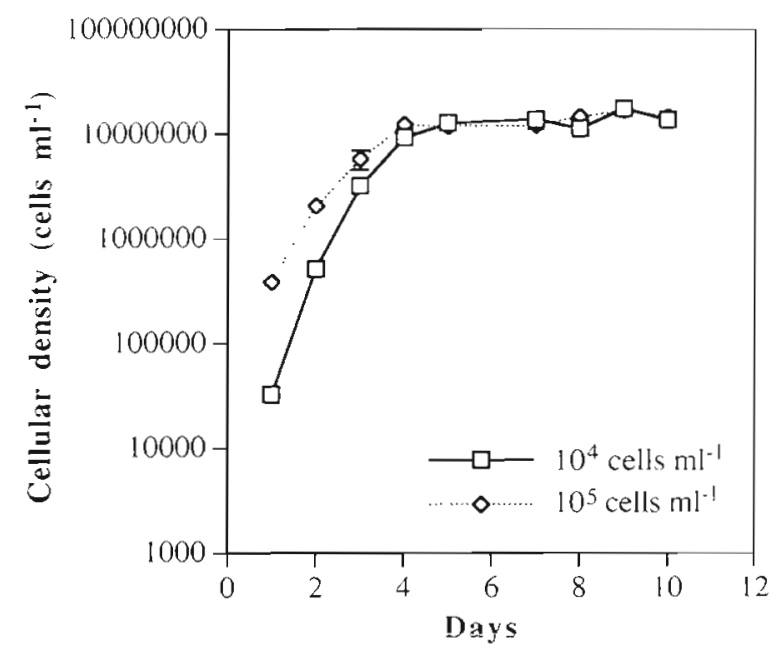

Fig. 5. Perkinsus atlanticus. Effect of inoculum density on in vitro growth. Results are shown as mean with standard deviation $(\mathrm{n}=4)$

Temperature conditions affected growth of Perkinsus atlanticus (Fig. 6). At $5^{\circ} \mathrm{C}$ no growth occurred, although the culture did not die which happened on the sixth day at $37^{\circ} \mathrm{C}$. At the other temperatures tested, 16,20 and $26^{\circ} \mathrm{C}$, the final cellular density was $1.5 \times$ $10^{7}$ cells ml ${ }^{-1}$ on the ninth day after inoculation, but this density was reached earlier at 20 and $26^{\circ} \mathrm{C}$ (seventh day) than at $16^{\circ} \mathrm{C}$ (ninth day). Subsequently, cultures reached a stationary phase.

Perkinsus atlanticus showed high tolerance to different salinities (Fig. 7). On the eleventh day, the cultures conducted at the 4 salinities tested showed approximately the same cellular density (between $1.1 \times 10^{7}$

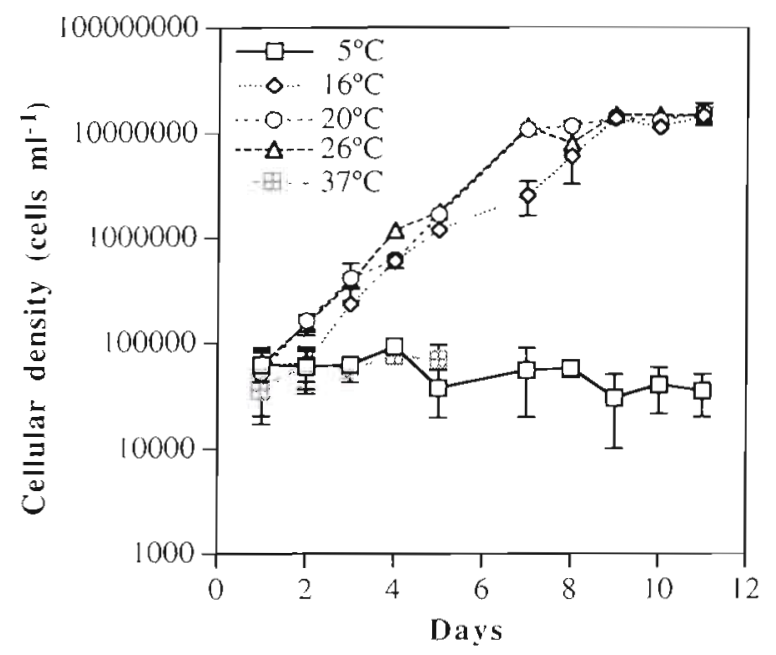

Fig. 6. Perkinsus atlanticus. Effect of temperature on in vitro growth. Results are shown as mean with standard deviation $(n=4)$

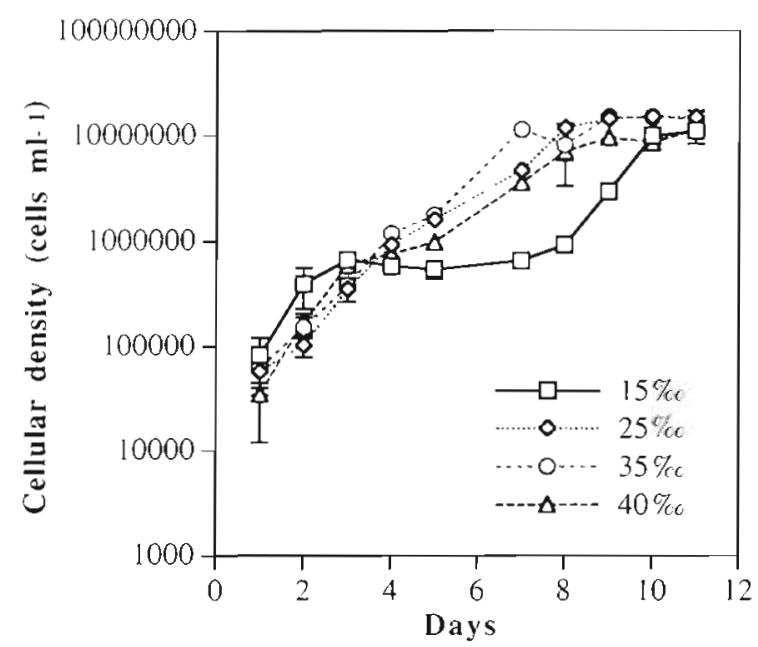

Fig. 7. Perkinsus atlanticus. Effect of salinity on in vitro growth. Results are shown as mean with standard deviation $(\mathrm{n}=4)$

and $1.5 \times 10^{7}$ cells ml ${ }^{-1}$ ). At 25,35 and $40 \%$ the maximum was obtained on the eighth day, but at $15 \%$ this cellular density was not reached until the tenth day. Subsequently, the number of $P$. atlanticus cells remained stationary.

Culture conditions did not affect size or shape of the parasite.

\section{Cryopreservation}

The frozen culture recovered well under normal culture conditions, reaching maximum abundance $(1.3 \times$ $10^{7}$ cells $\mathrm{ml}^{-1}$ ) by the ninth day (Fig. 8 ).

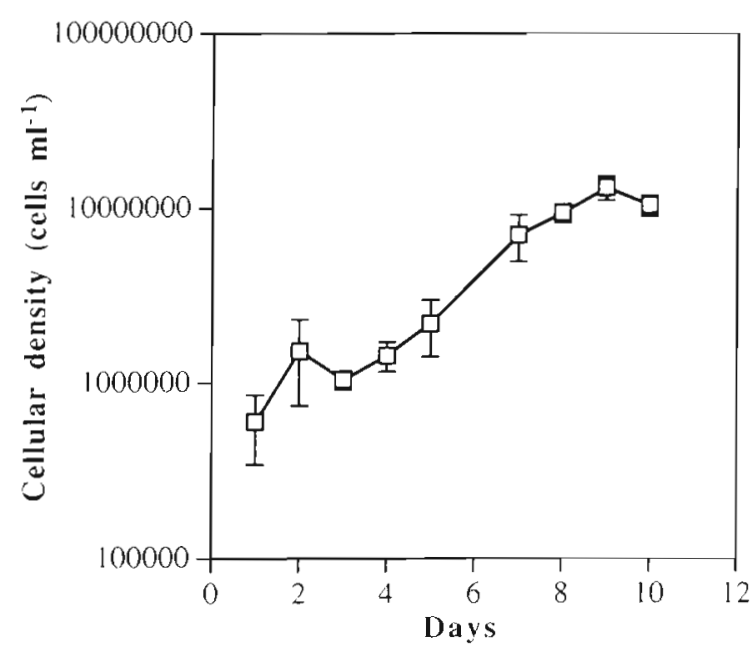

Fig. 8. Perkinsus atlanticus. Growth rate after cryopreservation for 5 mo. Results are shown as mean with standard deviation $(n=4)$ 


\section{DISCUSSION}

The morphology of the anterior flagellum of the zoospores, with a unilateral array of filamentous mastigonemes, leads us to conclude that the parasite does not belong to the thraustochytrids. Moreover, laminated walls, characteristic of the thraustochytrids were never observed using transmission electron microscopy. The absence of ectoplasmic nets in our Perkinsus cultures provided further evidence that the cells were not thraustochytrids nor were the cultures contaminated by thraustochytrids (Perkins 1973).

Although Perkinsus atlanticus has been associated with clam mortalities along the European Atlantic coast, few studies have been completed on this parasite, in contrast to the case of the oyster parasite $P$. marinus. To our knowledge this is the first time that $P$. atlanticus has been continuously cultured. Similar to the studies of $P$. marinus, this will facilitate research on important aspects of the biology of this pathogen, such as molecular biology, virulence and host-pathogen interactions.

Although the life cycle stages observed here agree in general with those which Azevedo et al. (1990) described for Perkinsus atlanticus and for several other Perkinsus species under culture Gauthier \& Vasta 1993, 1995, Kleinschuster \& Swink 1993, La Peyre et al. 1993, Kleinschuster et al. 1994, Gauthier et al. 1995, La Peyre 1996, Perkins 1996), there are some differences. For instance, contrary to what happens in $P$. marinus (Perkins 1996), P. atlanticus zoosporulation in DMEM: Ham's F-12 (1:2) with $50 \mathrm{mM}$ Hepes buffer and $3.5 \mathrm{mM}$ sodium bicarbonate plus $5 \%$ FBS is relatively common. This constitutes a massive event when ASW is used as supporting medium, as previously described for $P$. atlanticus by Azevedo et al. (1990) and AuzouxBordenave et al. (1995).

The hemocytometer was employed for growth rate assessment because of its ease of use and its accuracy when compared with other methods such as tritiated thymidine incorporation, digital image processing techniques, tetrazolium-based cell proliferation assays and optical density readings at $600 \mathrm{~nm}$ (Dungan \& Hamilton 1995, Gauthier \& Vasta 1995, La Peyre 1996, authors unpubl. obs.).

The medium proposed by Gauthier \& Vasta (1995) suited the requirements of Perkinsus atlanticus, providing good growth rates and allowing completion of the life cycle. This culture medium was also selected because of its simplicity of preparation in contrast to that of La Peyre et al. (1993)

Contrary to previous reports on Perkinsus marinus (Gauthier \& Vasta 1995, La Peyre 1996), P. atlanticus grew very well in MEM with $0.25 \%$ sodium bicarbonate supplemented with FBS, showing very similar growth rates to that in DMEM:Ham's F-12 (1:2) with $50 \mathrm{mM}$ Hepes buffer and $3.5 \mathrm{mM}$ sodium bicarbonate plus FBS. MEM with $0.25 \%$ sodium bicarbonate supplemented with FBS should be retained, at least for $P$. atlanticus, as an alternative culture medium. Use of FBS enhanced the growth of $P$. atlanticus in both tested media IDMEM:Ham's F-12 (1:2) with 50 mM Hepes buffer and $3.5 \mathrm{mM}$ sodium bicarbonate, and MEM with $0.25 \%$ sodium bicarbonate). Interestingly, Gauthier \& Vasta (1995) and Gauthier et al. (1995) reported dissimilar results for $P$. marinus. These authors described that an increment of more than $5 \%$ in the concentration of FBS used in DMEM:Ham's F-12 (1:2) with $50 \mathrm{mM}$ Hepes buffer and $3.5 \mathrm{mM}$ sodium bicarbonate decreased the growth rate. These differences between the 2 species could be related to several physiological aspects, including differences in their virulence.

Perkinsus atlanticus can adapt to very different salinity and temperature conditions, with similar growth rates at the different temperatures tested, except for extreme temperatures of 5 and $37^{\circ} \mathrm{C}$. $P$. atlanticus cultures showed similar high growth rates in the 16 to $26^{\circ} \mathrm{C}$ range, while $P$. marinus is reported to have an optimal growth rate in a narrower $\left(28\right.$ to $\left.32^{\circ} \mathrm{C}\right)$ temperature range (Gauthier \& Vasta 1995). Both species, $P$. marinus and $P$. atlanticus, tolerate similar salinity, 15 to $40 \%$. In previous field studies the presence of Perkinsus sp. was reported in Galicia at sampling sites where the salinity ranged from 23 to $30 \%$ at $9^{\circ} \mathrm{C}$ (Figueras et al. 1992)

The inoculum density did not affect the final cellular density in the culture of Perkinsus atlanticus. This is also different with cultured $P$. marinus (Gauthier \& Vasta 1995), for which the cellular density was directly proportional to the inoculum density.

The culture of Perkinsus atlanticus has been maintained continuously for more than 9 mo (100 passages) without decay. Presently, at the time of this article's completion, the culture is being maintained with 1 passage $\mathrm{wk}^{-1}$. The medium is then partially $(50 \%)$ changed. The frozen cultures have been repeatedly recovered giving good growth rates.

Several aspects (molecular biology, virulence and effect on the host defense mechanisms) of this cultured Perkinsus atlanticus are currently being investigated. This will allow the clarification of the reasons behind observations such as geographical variation in virulence and differences in susceptibility among bivalve species. Cultured $P$. atlanticus can be used as another bivalve-pathogen model that will allow us to study the disease process in these animals.

Acknowledgements. The authors thank Dr B. Novoa for her help in the preparation of media, handling of cultures and her suggestions in several steps of the work presented in this 
paper The work was partially funded by CICYT (Spain, Accion especial MAR 95-1862-E). M.C.O. thanks Xunta de Galicia for a research fellowship.

\section{LITERATURE CITED}

Andrews JD (1996) History of Perkinsus marinus, a pathogen of oysters in Cheasapeake Bay 1950-1984. J Shellfish Res 15(1):13-16

Auzoux-Bordenave S, Vigario AM, Ruano F, Domart-Coulon I, Doumenc D (1995) In vitro sporulation of the clam pathogen Perkinsus atlanticus (Apicomplexa, Perkinsea) under various environmental conditions. J Shellfish Res 14(2):469-475

Azevedo C (1989) Fine structure of Perkinsus atlanticus n. sp. (Apicomplexa, Perkinsea) parasite of the clam Ruditapes decussatus from Portugal. J Parasitol 75(4):627-635

Azevedo C, Corral L, Cachola R (1990) Finc structure of zoo sporulation in Perkinsus atlanticus (Apicomplexa, Perkinsea). Parasitology 100351-358

Burreson EM, Alvarez RS, Martinez VV, Macedo LA (1994) Perkinsus marinus (Apicomplexa) as a potential source of oyster Crassostrea virginica mortality in coastal lagoons of Tabasco, Mexico. Dis Aquat Org 20:77-82

Dungan CF, Hamilton RM (1995) Use of a tetrazolium-based cell proliferation assay to measure effects of in vitro conditions on Perkinsus marinus (Apicomplexa) proliferation. J Eukaryot Microbiol 42:379-388

Figueras A, Robledo JAF, Novoa B (1992) Occurrence of haplosporidian and Perkinsus-like infections in carpetshell clams, Ruditapes decussatus (Linnaeus, 1758), of the Ra de Vigo (Galicia, NW Spain). J Shellfish Res 11(2): $377-382$

Figueras A, Robledo JAF, Novoa B (1996) Brown ring disease in clams (Ruditapes decussatus and $R$. philippinarum) from Spain and Portugal. J Shellfish Res 15(2):363-368

Fisher WS, Oliver LM (1996) A whole-oyster procedure for diagnosis of Perkinsus marinus disease using Ray's fluid thioglycollate culture medium. J Shellfish Res 15(1): $109-117$

Gauthier JD, Feig B, Vasta GR (1995) Effect of fetal bovine serum glycoproteins on the in vitro proliferation of the oyster parasite Perkinsus marinus: development of a fully defined medium. J Eukaryot Microbiol 42(3):307-313

Gauthier JD, Vasta GR (1993) Continuous in vitro culture of the eastern oyster parasite Perkinsus marinus. J Invertebr Pathol 62:321-323

Gauthier JD, Vasta GR (1995) In vitro culture of the eastern oyster parasite Perkinsus marinus: optimization of the methodology. J Invertebr Pathol 66:156-168

Goggin CL, Lester RJG (1.987) Occurrence of Perkinsus species (Protozoa, Apicomplexa) in bivalves from the Great Barrier Reef. Dis Aquat Org 3:113-117

Goggin CL, McGladdery SE, Whyte SK, Cawthorn RJ (1996) An assessment of lesions in bay scallops Argopecten

Editorial responsibility: Albert Sparks,

SeattJe, Washington, USA irradians attributed to Perkinsus karlssoni (Protozoa, Apicomplexa). Dis Aquat Org 24:77-80

Kleinschuster SJ, Perkins FO, Dykstra MJ, Swink SL (1994) The in vituo life cycle of a Perkinsus species (Apicomplexa, Perkinsidae) isolated from Macoma balthica (Linnaeus, 1758). J Shellfish Res 13:416-466

Kleinschuster SJ, Swink SL (1993) A simple method for the in vitro culture of Perkinsus marinus. Nautilus 107:76-78

La Peyre JF (1996). Propagation and in vitro studies of Perkinsus marinus. J Shellfish Res 15(1):89-101

La Peyre JF, Faisal M, Burreson EM (1993) In vitro propagation of the protozoan Perkinsus marinus, a pathogen of the eastern oyster, Crassostrea virginica. J Eukaryot Microbiol 40(3):304-310

Lester RJG, Davis GHG (1981) A new Perkinsus species (Apicomplexa, Perkinsea) from the abalone Haliotis ruber. $J$ Invertebr Pathol 37:181-187

Levine ND (1978) Perkinsus gen n. and other new taxa in the protozoan phylum Apicomplexa. J Parasitol 64:549

Mackin JG, Owen HM, Collier A (1950) Preliminary note on the occurrence of a new protistan parasite, Dermocystidium marinum n. sp. in Crassostrea virginica (Gmelin). Science 111:328-329

Mackin JG, Ray SM (1966) The taxonomic relationship of Dermocystidium marinum Mackin, Owen and Collier. $\mathrm{J}$ Invertebr Pathol 8:544-545

McGladdery SE, Cawthorn RJ, Bradford BC (1991) Perkinsus karlssoni n. sp. (Apicomplexa) in bay scallops Argopecten irradians. Dis Aquat Org 10:127-1.37

Norton JH, Shepherd MA, Perkins FP, Prior HC (1993) Perkinsus-like infection in farmed golden-lipped pearl oyster Pinctada maxima from the Torres Strait, Australia. J Invertebr Pathol 62:105-106

Perkins FO (1973) A new species of marine labyrinthulid Labyrinthuloides yorkensis gen. et spec. nov. cytology and fine structure. Arch Mikrobiol 90:1-17

Perkins FO (1985) Range and host extensions for the molluscan bivalve pathogens. Perkinsus spp. Abstract, VII Int Congress of Protozoology, 1985, Nairobi, p 81

Perkins FO (1996) The structure of Perkinsus marinus (Mackin, Owen and Collier, 1950) Levine, 1978 with comments on taxonomy and phylogeny of Perkinsus spp. J Shellfish Res 15(1):67-87

Perkins FO, Menzel RW (1967) Ultrastructure of sporulation in the oyster pathogen Dermocystidium marinum. J Invertebr Pathol 9:205-229

Ray SM (1954) Biological studies of Dermocystidium marinum. Rice Inst Pam 41(Spec Iss): 1- 114

Ray SM (1996) Historical perspective on Perkinsus marinus disease of oysters in the Gulf of Mexico. J Shellfish Res 15(1):9-11

Whyte SK, Cawthorn RJ, MacMillan RJ, Desprès B (1993) Isolation and purification of developmental stages of Perkinsus karlssoni (Apicomplexa: Perkinsea), a parasite affecting bay scallops Argopecten irradians. Dis Aquat Org 15: $199-205$

Submitted: April 29, 1997; Accepted: February 26, 1998 Proofs received from author(s): June 9, 1998 